\title{
Evaluating the nutritional condition of individual whitefish (Coregonus spp.) larvae by the RNA/DNA ratio
}

\author{
M. Steinhart and R. ECKManN \\ Limnological Institute, University of Constance, P.O. Box 5560, D-7750 Konstanz. \\ Germany
}

(Received 28 June 1991, Accepted 21 October 199I)

\begin{abstract}
Larvae of Coregonus spp. were reared in the laboratory under different temperature 14.6 and 8 C) and feeding conditions (ad libitum. limited, with starvation intervals). Their RNA DNA ratios were determined with a highly sensitive fluorescence technique. After resorption of their yolk reserves (about 2 weeks after hatching), well fed larvae (RNA DNA >2.5) could be significantly distinguished from larvae reared under limited food supply (RNA.DNA $<2.5$ ), both at the 6 and 8 Clevels. At 4 C. no diflerences due to the feeding regime were found. During a second series of experiments. larvae were affected by an intestinal disease, which was caused by the ingestion of unsuitable copepod plankton. This disease provoked high mortality. decreased growth and RNA DNA ratios which were almost as low as in temporarily starved larvac from the first scrics. Coregonid larvac sampled in Lake Constance during spring 1990 showed RNA/DNA ratios which were unexpectedly low when judged on the basis of mean body length and average ambient temperature. It was obvious from maeroscopic observations that some of these wild larvae were severely attacked by the intestinal disease. The low RNA DNA ratios in field samples are, therefore, interpreted as a sublethal result of this discase.
\end{abstract}

Key words: RNA DNA ratio: nutritional condition; coregonid larvae: intestinal discase

\section{INTRODUCTION}

Studying the effects of biotic and abiotic factors on year-class strength is one of the major areas in fisheries research. It is generally accepted that fish stock sizes are mainly determined during early life history (May. 1974). Survival of young fish can be controlled both by predation and starvation (Hunter. 1984), or by the interaction of these two factors, because starving fish larvae are more vulnerable to predation (Purcell et al , 1987). The nutritional condition of larval fish, which is the key factor in this context, can be characterized histologically (O'Connell. 1976; Theilacker, 1986; Oozeki et al. 1989), by measuring proteolytic enzymes (Pedersen et al., 1987; Ueberschär, 1988), or by the RNA DNA ratio (Buckley, 1979, 1980, 1984: Martin et al., 1985; Robinson \& Ware, 1988; Clemmesen, 1988, 1989, 1990).

The RNA concentration is a sensitive parameter to determine the growth rate of an organism because it is the organizer of protein synthesis (Bulow, 1970). DNA concentration represents an index of cell numbers since cellular DNA content is insensitive to changes in environmental conditions (Dortch et al., 1983). The ratio of RNA to DNA is, therefore, a more accurate index of metabolic activity than RNA concentration alone. because this ratio is not affected by the number or size of cells in a tissue sample (Haines, 1973). Clemmesen (1988) developed a highly sensitive fluorescence technique which allows determination of nucleic acids in concentrations as low as $0 \cdot 1 \mu \mathrm{g} \mathrm{ml}^{-1}$, i.e. in individual fish larvae of only $25 \mu \mathrm{g}$ dry weight. Therefore not only the mean nutritional status of a fish population, 
but also interindividual variability can be assessed. This method was used in the present study, but slightly modified according to the higher larval dry weight (minimum $0.6 \mathrm{mg}$ ).

Whitefish (Coregonus spp.) larvae were reared in the laboratory under different temperature and feeding conditions which simulated the conditions existing in Lake Constance. Their RNA/DNA ratios were taken as reference values in an attempt to characterize the nutritional status of whitefish larvae sampled in the lake.

\section{MATERIALS AND METHODS}

\section{AQUARIA EXPERIMENTS}

Two successive series of experiments were run. One batch of artificially fertilized eggs of Coregonus spp. was split into two groups and incubated separately. Hatching dates of the two larval groups were manipulated by selecting the appropriate incubation temperatures (Eckmann, 1987).

Freshly hatched larvae were stocked in nine aquaria with a volume of $12 \mathrm{l}$ each. Water temperatures were adjusted to 4,6 and $8 \mathrm{C}( \pm \mathrm{I} \cdot 0 \mathrm{C})$ and a $14: 10 \mathrm{~h}$ light/dark rhythm was provided. Live zooplankton (mainly $C$ yclops vicinus) was collected daily or every second day in the lake with a $500 \mu \mathrm{m}$ plankton net. At each temperature level, three feeding regimes were established: (1) food was given three or four times a day in excess ("ad libitum "): (2) food was given only once per day and $2 \mathrm{~h}$ later most of the remaining zooplankton was siphoned off (' limited '): (3) feeding was similar to the second group. but after every 8 to 12 days of feeding larvae were exposed to a starvation interval of 4 to 5 days ("starved "). Aquaria were cleaned daily and dead larvae counted.

Up to an age of 44 days, samples of living larvae were taken every 14 days for further analyses. In the case of 'starved' larvae. samples were taken following the starvation intervals. Larvae were killed with TCMP (trichlormethyl-propanole, $1.5 \mathrm{~g} \mathrm{I}^{1}$ ), examined under a microscope for fullness of the gut and checked for possible damage. Length was measured to the nearest $0.1 \mathrm{~mm}$. Each larva was transferred into an Eppendorf-vial. shock-frozen with liquid nitrogen and stored at $-70^{\circ} \mathrm{C}$.

\section{FIELD SAMPLING}

On 4 days in March/April 1990, larvae of Coregonus spp. were sampled in Lake Constance. They were caught with a conical plankton net of $1.5 \mathrm{~m}$ diameter and $4.5 \mathrm{~m}$ length. with mesh sizes of $1200 \mu \mathrm{m}$ near the aperture and $900 \mu \mathrm{m}$ in the rear part. Surface trawls were made near the shore at approximately $1.5 \mathrm{~m} \mathrm{~s}$. After several tows of $15 \mathrm{~min}$ each, sampled larvae were killed with TCMP, measured, shock-frozen with liquid nitrogen. and stored on dry ice until arrival at the laboratory.

\section{EXTRACTION OF NUCLEIC ACIDS}

The extraction procedure developed by Clemmesen (1988) for marine fish larvae was adapted to the higher dry weight of coregonid larvae $(0.6-10 \mathrm{mg})$. By means of a teflon pistil, individual larvae were homogenized for $1 \mathrm{~min}$ on ice in $1 \mathrm{ml} \mathrm{STE} \mathrm{buffer}(0.05 \mathrm{~m}$ Tris $\mathrm{HCl}$ buffer containing $0.1 \mathrm{M} \mathrm{NaCl}$ and $0.01 \mathrm{M}$ EDTA) at $\mathrm{pH} \mathrm{7.5}$, which contained $0.2 \mathrm{mg}$ $\mathrm{ml}^{-1}$ proteinase $\mathrm{K}$. All further steps were carried out at room temperature. After adding $100 \mu \mathrm{l}$ of $20 \%$ sodium dodecyl sulphate (SDS), the sample was shaken for $15 \mathrm{~min}$ and centrifuged at $8000 \mathrm{~g}$ for $15 \mathrm{~min}$. From the supernatant, $0.5 \mathrm{ml}$ was transferred to a new $1.5 \mathrm{ml}$ vial and $0.5 \mathrm{ml}$ of a $1: 1$ mixture of phenol-8-hydroxyquinoline $(1: 0.001)$ and chloroform-isoamylalcohol $(24: 1)$ was added. After shaking and centrifuging for $10 \mathrm{~min}$ each, the aqueous phase was transferred to a new vial and the phenol chloroform phase was discarded. This extraction was carried out twice. To remove phenol residues from the aqueous solution, the sample was washed twice with chloroform-isoamylalcohol by shaking for $5 \mathrm{~min}$, followed by $5 \mathrm{~min}$ of centrifugation. Finally, two $0.1 \mathrm{ml}$ aliquots of the purified nucleic acid solution were transferred to sterilized test tubes containing $2.4 \mathrm{ml}$ of STE buffer at $\mathrm{pH} 7 \cdot 5$. 


\section{DETERMINATION OF NUCLEIC ACIDS}

Two specific fluorophors which react with nucleic acids were used. Ethidium bromide (EB) was used to determine DNA and RNA simultaneously, bisbenzimidazole (BB) was used to determine DNA alone (Clemmesen, 1988). After measuring the autofluorescence of the sample aliquots, the fluorescent dyes were added in final concentrations of $1 \times 10^{5} \mathrm{M}$ (EB) (Le Pecq \& Paoletti, 1966) and $1.6 \times 10^{-6} \mathrm{M}$ (BB) (Cesarone et al, 1979). The EB-fluorescence was determined at $365 \mathrm{~nm}$ excitation and $590 \mathrm{~nm}$ emission wavelength, the BB-fluorescence at $352 \mathrm{~nm}$ excitation and $448 \mathrm{~nm}$ emission wavelength (Clemmesen, 1988) at $22 \mathrm{C}$

Calibration curves for DNA and RNA with EB and BB were established as proposed by Clemmesen (1990). Instead of measuring the fluorescence intensity of pure standards, the standards were mixed with aliquots of a fish homogenate and submitted to the extraction process before the measurement. Pure fish homogenate was used as a control. In this way, a possible influence of the fish homogenate on the efficiency of the nucleic acid extraction is taken into account.

Sample nucleic acid concentrations were calculated as follows: the DNA concentration determined with BB was used to estimate the EB-fluorescence caused by DNA. This estimate was then subtracted from the total EB-fluorescence. and the EB-fluorescence caused by RNA was obtained. Finally, the RNA concentration was read from the RNA-EB calibration curve.

Sample means were compared using the $t$-test $(P<0 \cdot 05)$. Since the sample numbers were quite small, barely significant results were also compared by the Mann-Whitney U-test, which confirmed the results obtained by the $t$-test.

\section{RESULTS}

\section{AQUARIA EXPERIMENTS}

In the first series of experiments, larvae developed normally and grew well under the given temperature and food conditions. During the second series, however, growth was stunted and a dramatic increase of mortality occurred. These symptoms were caused by an intestinal disease which has already been described by Eekmann (1985) and Eckmann et al. (1986). It is directly connected with the ingestion of spring copepod plankton. while the ultimate cause of the disease is still unknown.

Cumulative mortalities and sample means of total length and RNA/DNA ratio of the first series of experiments are shown in Table 1 . At 4 C, no significant increase of body length or RNA/DNA ratio could be observed at all. At 6 and 8 C. larvae fed "adlibitum " showed significant increases in RNA/DNA ratio from day 13 to day 27 and further to day 40 , although the latter increases were not significant at $P<0 \cdot 05$. The RNA DNA ratio of larvae receiving a "limited 'diet increased significantly at 6 C from day 13 to day 27 and then remained unchanged, while the gradual increase at $8^{\circ} \mathrm{C}$ was not significant. 'Starved ' fish did not show any significant changes in RNA/DNA ratio during the whole experiment.

Within the 6 and $8^{\circ} \mathrm{C}$ temperature levels, the three different feeding regimes did not yield different RNA/DNA ratios at 13 days. However, after 27 , and more so after 40 days of feeding, significant differences occurred between 'ad libitum ' and 'limited 'larvae as well as between 'ad libitum' and 'starved' larvae, while "limited" and 'starved" larvae could never be differentiated significantly by their RNA/DNA ratios.

Comparing the three temperature levels, different $\mathrm{RNA}$ DNA ratios were only found at the age of 40 days under ' ad libitum ' food conditions: at 4 C, the ratio was significantly lower than at 6 and $8^{\circ} \mathrm{C}$, while it did not differ significantly 
TABLE I. Mean RNA/DNA ratios and body lengths ( \pm 1 S.D.), and cumulative mortalities $\left(M^{\%} \%\right)$ of whitefish (Coregonus spp.) larvae reared under three feeding regimes, (see text for details) at three temperature levels, first series of experiments 12 February-27 March 1990

\begin{tabular}{|c|c|c|c|c|c|c|}
\hline $\begin{array}{l}\text { Temperature } \\
\text { (C) }\end{array}$ & $\begin{array}{l}\text { Feeding } \\
\text { regime }\end{array}$ & Days & $n$ & RNA/DNA & $\begin{array}{c}\text { Length } \\
(\mathrm{mm})\end{array}$ & $\begin{array}{c}M \\
(\%)\end{array}$ \\
\hline \multirow[t]{3}{*}{4} & 'Ad libitum' & $\begin{array}{l}13 \\
27 \\
40\end{array}$ & $\begin{array}{l}4 \\
9 \\
9\end{array}$ & $\begin{array}{l}1 \cdot 9 \pm 0 \cdot 1 \\
2 \cdot 6 \pm 0 \cdot 9 \\
2 \cdot 2 \pm 0 \cdot 5\end{array}$ & $\begin{array}{l}12 \cdot 3 \pm 0.6 \\
13 \cdot 3 \pm 0.5 \\
14.1 \pm 1.4\end{array}$ & $\begin{array}{r}1 \cdot 1 \\
2 \cdot 7 \\
15 \cdot 7\end{array}$ \\
\hline & 'Limited' & $\begin{array}{l}13 \\
27 \\
40\end{array}$ & $\begin{array}{r}5 \\
10 \\
7\end{array}$ & $\begin{array}{l}1.9 \pm 0.9 \\
2 \cdot 7 \pm 0 \cdot 8 \\
2 \cdot 4 \pm 0 \cdot 8\end{array}$ & $\begin{array}{l}12 \cdot 3 \pm 0 \cdot 7 \\
12 \cdot 9 \pm 0 \cdot 9 \\
13 \cdot 5 \pm 1 \cdot 0\end{array}$ & $\begin{array}{c}0 \\
0 \\
11 \cdot 4\end{array}$ \\
\hline & 'Starved" & $\begin{array}{l}17(5) \\
28(5) \\
39(4)\end{array}$ & $\begin{array}{r}4 \\
10 \\
9\end{array}$ & $\begin{array}{l}2 \cdot 0 \pm 0 \cdot 6 \\
2 \cdot 9 \pm 0 \cdot 6 \\
2 \cdot 1 \pm 0 \cdot 6\end{array}$ & $\begin{array}{l}12.6 \pm 0.3 \\
12.7 \pm 0.8 \\
13.2 \pm 0.8\end{array}$ & $\begin{array}{l}0 \\
0 \\
3 \cdot 6\end{array}$ \\
\hline \multirow[t]{3}{*}{6} & 'Ad libitum' & $\begin{array}{l}13 \\
27 \\
40\end{array}$ & $\begin{array}{r}5 \\
10 \\
10\end{array}$ & $\begin{array}{l}2 \cdot 0 \pm 0 \cdot 3 \\
3 \cdot 2 \pm 0 \cdot 6 \\
4 \cdot 3 \pm 1 \cdot 3\end{array}$ & $\begin{array}{l}12 \cdot 6 \pm 1 \cdot 0 \\
14 \cdot 5 \pm 1 \cdot 4 \\
18 \cdot 7 \pm 3 \cdot 7\end{array}$ & $\begin{array}{l}0 \\
0 \\
2 \cdot 7\end{array}$ \\
\hline & 'Limited' & $\begin{array}{l}13 \\
27 \\
40\end{array}$ & $\begin{array}{r}5 \\
10 \\
9\end{array}$ & $\begin{array}{l}1 \cdot 5 \pm 0 \cdot 3 \\
2 \cdot 6 \pm 0 \cdot 7 \\
2 \cdot 7 \pm 1 \cdot 1\end{array}$ & $\begin{array}{l}12 \cdot 8 \pm 0 \cdot 6 \\
13 \cdot 1 \pm 0 \cdot 7 \\
15 \cdot 5 \pm 1 \cdot 9\end{array}$ & $\begin{array}{r}2 \cdot 0 \\
5 \cdot 0 \\
19 \cdot 4\end{array}$ \\
\hline & 'Starved' & $\begin{array}{l}17(5) \\
28(5) \\
39(4)\end{array}$ & $\begin{array}{r}5 \\
10 \\
8\end{array}$ & $\begin{array}{l}1 \cdot 8 \pm 0 \cdot 4 \\
2 \cdot 3 \pm 0 \cdot 5 \\
1 \cdot 8 \pm 0 \cdot 8\end{array}$ & $\begin{array}{l}13 \cdot 0 \pm 0 \cdot 6 \\
13 \cdot 1 \pm 0 \cdot 8 \\
14 \cdot 1 \pm 0 \cdot 9\end{array}$ & $\begin{array}{r}2 \cdot 1 \\
3 \cdot 7 \\
28 \cdot 6\end{array}$ \\
\hline \multirow[t]{3}{*}{8} & Adlibitum' & $\begin{array}{l}13 \\
27 \\
40\end{array}$ & $\begin{array}{r}5 \\
10 \\
10\end{array}$ & $\begin{array}{l}2 \cdot 0 \pm 0 \cdot 4 \\
3 \cdot 4 \pm 1 \cdot 2 \\
4 \cdot 5 \pm 1 \cdot 3\end{array}$ & $\begin{array}{l}14 \cdot 1 \pm 0 \cdot 8 \\
19 \cdot 0 \pm 3 \cdot 7 \\
20 \cdot 8 \pm 2 \cdot 5\end{array}$ & $\begin{array}{l}0 \\
0 \\
0\end{array}$ \\
\hline & 'Limited" & $\begin{array}{l}13 \\
27 \\
40\end{array}$ & $\begin{array}{r}6 \\
10 \\
9\end{array}$ & $\begin{array}{l}1.8 \pm 0.6 \\
2 \cdot 1 \pm 0.5 \\
2.3 \pm 0.8\end{array}$ & $\begin{array}{l}13 \cdot 0 \pm 0 \cdot 8 \\
14 \cdot 1 \pm 1 \cdot 6 \\
16 \cdot 1 \pm 1 \cdot 8\end{array}$ & $\begin{array}{r}1 \cdot 0 \\
7 \cdot 0 \\
29 \cdot 6\end{array}$ \\
\hline & 'Starved' & $\begin{array}{l}17(5) \\
28(5) \\
39(4)\end{array}$ & $\begin{array}{r}4 \\
10 \\
5\end{array}$ & $\begin{array}{l}1.9 \pm 0.4 \\
1.9 \pm 0.6 \\
1.9 \pm 0.2\end{array}$ & $\begin{array}{l}12 \cdot 8 \pm 0.7 \\
13.5 \pm 0.9 \\
14.2 \pm 0.6\end{array}$ & $\begin{array}{c}0 \\
4 \cdot 6 \\
55 \cdot 3\end{array}$ \\
\hline
\end{tabular}

Days are counted from the first day of feeding. i.e. 1 to 3 days after hatching: in the case of starved larvae. the number of days starved before samples were taken are given in parentheses: $n$ is the number of larvae analysed in each sample.

between 6 and $8 \mathrm{C}$. 'Limited" and 'starved" larvae from the three temperature levels could not be distinguished by their RNA/DNA ratios.

As a consequence of the intestinal disease, cumulative mortality was always much higher in the second series of experiments (Table II). Body length increased gradually in all groups, but growth rates were lower than in the first series (cf. Tables I and II). RNA/DNA ratios did not change as a response to the different temperature and feeding levels due to the diseased state of the larvae.

Comparing the two series of experiments, it is striking that diseased larvae almost always showed significantly lower RNA/DNA ratios. Moreover, "ad libitum' larvae from the second series in some cases had even lower RNA/DNA ratios than "starved 'larvae of the same age from the first series. 
TABIf II. Second series of experiments, 26 March-10 May 1990, (for further explanations see Table I)

\begin{tabular}{|c|c|c|c|c|c|c|}
\hline $\begin{array}{l}\text { Temperature } \\
\text { (C) }\end{array}$ & $\begin{array}{l}\text { Feeding } \\
\text { regime }\end{array}$ & Days & $n$ & RNA DNA & $\begin{array}{l}\text { Length } \\
(\mathrm{mm})\end{array}$ & $\begin{array}{c}M \\
(\%)\end{array}$ \\
\hline \multirow[t]{3}{*}{4} & 'Adlihitum & $\begin{array}{l}13 \\
27 \\
41\end{array}$ & $\begin{array}{r}10 \\
5 \\
10\end{array}$ & $\begin{array}{l}1.5 \pm 0.4 \\
1.8 \pm 0.6 \\
2.4 \pm 0.9\end{array}$ & $\begin{array}{l}13 \cdot 2 \pm 0 \cdot 5 \\
13 \cdot 2 \pm 0 \cdot 4 \\
14 \cdot 2 \pm 1 \cdot 8\end{array}$ & $\begin{array}{r}1 \cdot 0 \\
9 \cdot 3 \\
29 \cdot 0\end{array}$ \\
\hline & 'Limited' & $\begin{array}{l}13 \\
27 \\
41\end{array}$ & $\begin{array}{l}9 \\
5 \\
9\end{array}$ & $\begin{array}{l}1.9 \pm 0.2 \\
2 \cdot 0 \pm 1 \cdot 0 \\
2 \cdot 1 \pm 0.4\end{array}$ & $\begin{array}{l}13.1 \pm 0.5 \\
13.1 \pm 0.9 \\
13.9 \pm 0.8\end{array}$ & $\begin{array}{r}0.5 \\
15 \cdot 6 \\
23 \cdot 4\end{array}$ \\
\hline & 'Starved' & $\begin{array}{l}13(4) \\
27(4) \\
41(4)\end{array}$ & $\begin{array}{l}9 \\
5 \\
8\end{array}$ & $\begin{array}{l}1.4 \pm 0.4 \\
2.7 \pm 1.4 \\
1.7 \pm 0.4\end{array}$ & $\begin{array}{l}13 \cdot 1 \pm 0 \cdot 7 \\
13 \cdot 6 \pm 1 \cdot 0 \\
14 \cdot 0 \pm 0 \cdot 9\end{array}$ & $\begin{array}{r}1 \cdot 0 \\
15 \cdot 8 \\
23 \cdot 2\end{array}$ \\
\hline \multirow[t]{3}{*}{6} & 'Ad libitumi & $\begin{array}{l}13 \\
27 \\
41\end{array}$ & $\begin{array}{r}10 \\
5 \\
8\end{array}$ & $\begin{array}{l}1.8 \pm 0.5 \\
1.7 \pm 0.6 \\
2.0 \pm 0.7\end{array}$ & $\begin{array}{l}13 \cdot 2 \pm 0 \cdot 9 \\
14 \cdot 2 \pm 0 \cdot 9 \\
15 \cdot 3 \pm 1 \cdot 1\end{array}$ & $\begin{array}{r}1.7 \\
21.6 \\
41.6\end{array}$ \\
\hline & 'Limited' & $\begin{array}{l}13 \\
27 \\
41\end{array}$ & $\begin{array}{r}9 \\
5 \\
10\end{array}$ & $\begin{array}{l}2 \cdot 1 \pm 0.8 \\
1.6 \pm 0.5 \\
2 \cdot 1 \pm 0.7\end{array}$ & $\begin{array}{l}13 \cdot 2 \pm 0 \cdot 7 \\
13 \cdot 5 \pm 1 \cdot 0 \\
15 \cdot 3 \pm 1 \cdot 1\end{array}$ & $\begin{array}{r}1 \cdot 0 \\
22 \cdot 2 \\
35 \cdot 6\end{array}$ \\
\hline & 'Starved' & $\begin{array}{l}13(4) \\
27(4) \\
41(4)\end{array}$ & $\begin{array}{l}9 \\
5 \\
9\end{array}$ & $\begin{array}{l}1.3 \pm 0.5 \\
2.2 \pm 0.8 \\
1.5 \pm 0.3\end{array}$ & $\begin{array}{l}14 \cdot 1 \pm 3 \cdot 5 \\
13.9 \pm 1 \cdot 2 \\
15 \cdot 5 \pm 4 \cdot 4\end{array}$ & $\begin{array}{c}0 \\
23 \cdot 2 \\
36 \cdot 6\end{array}$ \\
\hline \multirow[t]{3}{*}{8} & 'Adlibitum' & $\begin{array}{l}13 \\
27 \\
41\end{array}$ & $\begin{array}{r}10 \\
5 \\
10\end{array}$ & $\begin{array}{l}2 \cdot 1 \pm 0.4 \\
1.5 \pm 0.5 \\
2 \cdot 2 \pm 0.6\end{array}$ & $\begin{array}{l}13 \cdot 7 \pm 3 \cdot 3 \\
14 \cdot 1 \pm 1 \cdot 5 \\
17 \cdot 4 \pm 1 \cdot 7\end{array}$ & $\begin{array}{r}4 \cdot 8 \\
31 \cdot 0 \\
34 \cdot 0\end{array}$ \\
\hline & 'Limited' & $\begin{array}{l}13 \\
27 \\
41\end{array}$ & $\begin{array}{r}10 \\
5 \\
6\end{array}$ & $\begin{array}{l}2.2 \pm 0.7 \\
1.9 \pm 0.4 \\
2.1 \pm 0.8\end{array}$ & $\begin{array}{l}14.1 \pm 3.0 \\
13 \cdot 5 \pm 0.8 \\
16.6 \pm 1.3\end{array}$ & $\begin{array}{r}1.8 \\
36 \cdot 9 \\
57 \cdot 9\end{array}$ \\
\hline & 'Starved' & $\begin{array}{l}13(4) \\
27(4) \\
41(4)\end{array}$ & $\begin{array}{r}10 \\
5 \\
3\end{array}$ & $\begin{array}{l}1 \cdot 4 \pm 0.6 \\
2 \cdot 0 \pm 0.5 \\
2 \cdot 0 \pm 0.6\end{array}$ & $\begin{array}{l}13 \cdot 7 \pm 1 \cdot 8 \\
13 \cdot 8 \pm 1 \cdot 0 \\
15 \cdot 0 \pm 2 \cdot 2\end{array}$ & $\begin{array}{r}0.9 \\
40 \cdot 3 \\
77 \cdot 9\end{array}$ \\
\hline
\end{tabular}

\section{HIELD SAMPLES}

Mean RNA/DNA ratios and body lengths of the field samples are given in Table IIl. There were no significant differences in body length between the four samples. The larvae caught on 18 April showed a significantly lower mean RNA DNA ratio than the other three samples. These three samples did not differ among each other in mean $\mathrm{RNA} / \mathrm{DNA}$ ratio (Table III).

Since the RNA/DNA ratio is influenced by temperature, the ambient temperature of wild larvae must be known in order to assess their nutritional condition. Surface temperature was measured every second to fifth day in the pelagic zone. Littoral temperatures may differ from these values by about \pm 2 C. In 1990 . coregonid larvae hatched mainly at the end of February (H. Quos, pers. comm.). From the end of February until 25 April, the last day of sampling, surface temperature increased from 5 to $8 \mathrm{C}$. Therefore mean ambient temperatures prior to sampling may be assumed as $6 \pm 2^{2} \mathrm{C}$ for larvae sampled on the first three dates. and $7 \pm 2 \mathrm{C}$ for larvae taken in the fourth sample. 
TABLE III. Mean RNA/DNA ratios and body lengths ( \pm 1 s.D.) of Coregonus spp. larvae sampled on four dates during spring 1990 in Lake Constance Obersee and Überlinger See; $n$ is sample size

\begin{tabular}{lcrcc}
\hline Date & $\begin{array}{c}\text { Mean ambient } \\
\text { temperature } \\
(\mathrm{C})\end{array}$ & $n$ & RNA/DNA & $\begin{array}{c}\text { Length } \\
\text { (min) }\end{array}$ \\
\hline 23 Mar. & 6 & 14 & $2 \cdot 0 \pm 0 \cdot 4$ & $14 \cdot 0 \pm 2 \cdot 1$ \\
4 Apr. & 6 & 29 & $1 \cdot 8 \pm 0 \cdot 6$ & $13.9 \pm 1 \cdot 1$ \\
18 Apr. & 6 & 5 & $1 \cdot 2 \pm 0 \cdot 3$ & $14.9 \pm 1 \cdot 1$ \\
$25 \mathrm{Apr}$. & 7 & 39 & $2 \cdot 0 \pm 0.5$ & $14.6 \pm 2 \cdot 8$ \\
\hline
\end{tabular}

\section{DISCUSSION}

The aim of the present study was to investigate whether the RNA/DNA ratio is a suitable indicator for the nutritional condition of individual coregonid larvae up to an age of 40 days.

In healthy laboratory-reared larvae, the differences between well-fed specimens and those which were reared under restricted food supply were evident at the 6 and 8 C levels: larvae with RNA/DNA ratios around 2.5 and lower must be regarded as undernourished. These differences were first detected in the second sample (27-days-old), while in younger larvae (13-days-old), no significant differences were found. Unfortunately the intervals between the samplings were rather long, so the changes of the $\mathrm{RNA} / \mathrm{DNA}$ ratio over time cannot be described more precisely at the moment. Furthermore, it was not possible at either age to distinguish significantly between larvae which were given a limited ration and those which were exposed to intermittent starvation intervals. This may be caused by the short length of the starvation intervals. Longer starvation intervals might lead to even lower RNA/DNA ratios, but these experimental conditions would no longer reflect the real situation in the lake. Nevertheless, at 6 and 8 C. mortality was clearly higher in "starved' larvae than in those larvae on 'limited ' rations.

A critical RNA/DNA ratio of 2.5 was also found for herring larvae (Clupea harengus L.) older than 10 days. In yolk sac herring larvae, however, no clear separation was possible between starved and fed specimens (Clemmesen, 1989). Robinson \& Ware (1988) also found increasing RNA/DNA ratios even in starved herring larvae until the end of the volk sac stage. It is suggested that coregonid larvae in the present study did not show any significant differences in RNA/DNA ratio as long as they were utilizing their yolk reserves. This is the case in 13-dayold coregonid larvae: at temperatures from 4 to $8 \mathrm{C}$ they were still utilizing their yolk reserves although they had started to ingest food during the first days after hatching. The subsequent rise of the RNA/DNA ratio with age in well-fed coregonid larvae has also been observed in striped bass (Morone saxalitis Walbaum) larvae (Martin et al., 1985) and in herring larvae (Clemmesen, 1989), while Buckley (1980) in winter flounder (Pseudopleuronectes americanus Walbaum) did not find any dependence on larval age.

The diseased larvae from the second series of experiments could not be classified with regard to their nutritional condition by means of the RNA/DNA ratio. The 
small differences in this parameter both within and between treatment groups were statistically not significant in any case. Furthermore. apart from suffering considerably higher mortalities and lower growth rates (Tables 1 and I1), the absolute RNA/DNA ratios of all treatment groups in this series were always well below the critical value of $2 \cdot 5$. These larvae must. therefore, be considered as severely affected by the ingestion of unsuitable zooplankton.

The application of the RNA/DNA ratio method to field samples is only possible with certain precautions. Knowing the age of individual larvae would aid considerably in the correct interpretation of the data. Determination of age by counting daily otolith increments, however, is not possible in wild coregonid larvae of Lake Constance (Klink \& Eckmann, in press). An additional problem arises, because every year several hundred millions of hatchery larvae are released in to the lake. Stocking takes place from March through May. so the field samples analysed in this study are probably composed of larvae of very different but unknown age.

Nevertheless, when mean body length is determined, it is possible to make some cautious statements about the nutritional condition of larvae sampled in the lake. From the mean larval lengths of 14.14 .6 and $14.8 \mathrm{~mm}$ and their ambient temperatures which ranged from 6 to $8^{-} \mathrm{C}$, it can be assumed that they were older than 2 weeks (Table I. 6 and $8^{\circ} \mathrm{C}$ ). Their RNA/DNA ratios should then be well above $2 \cdot 5$, had they lived under optimum food supply. Obviously, this was not the case (Table 111). The mean RNA/DNA ratios of the three field samples taken in April were similar to the ratios which were observed in diseased larvae reared in the laboratory (Table II), and in fact, in all three samples diseased larvae were present. Unfortunately, these larvae. which were easily identified by the symptoms described by Eckmann et al. (1986), were not treated separately in nucleic acid analyses; but it is assumed that all sampled larvae were affected by this disease in varying degrees, and this led to the unexpectedly low RNA/DNA ratios (only seven of 87 larvae had RNA/DNA ratios above $2 \cdot 5$ ). Barron \& Adelman (1984) examined the influence of toxicant stress on fathead minnows (Pimephales promelas Rafinesque) and found RNA, DNA and protein content per larva, like RNA/DNA ratio, to be sensitive to toxicant stress. A similar reaction might explain the low RNA/DNA ratios observed in diseased whitefish larvae in our study.

In summary, the RNA/DNA ratio can be used to characterize the nutritional condition of healthy coregonid larvae as well as to identify pathological situations. taking into account ambient temperature and the larva's age or length. How far this method can be used in wild larvae from Lake Constance, to decide the key question of whether they are food-limited or not, remains to be assessed under more favourable feeding conditions, i.e. when no zooplankton-based mortality occurs.

We thank the physicists at our institute for temperature data of Lake Constance. The study was supported by Deutsche Forschungsgemeinschaft within the Special Research Project (SFB 248) "Stoffhaushalt des Bodensees".

\section{References}

Barron, M. G. \& Adelman, I. R. (1984). Nucleic acid, protein content and growth of larval fish sublethally exposed to various toxicants. Canadian Journal of Fisheries and Aquatic Sciences 41, 141-150. 
Buckley, L. J. (1979). Relationships between RNA-DNA ratio, prey density, and growth rate in Atlantic cod (Gadus morhua) larvae. Journal of the Fisheries Research Board of C'anada 36, 1497-1502.

Buckley, L. J. (1980). Changes in ribonucleic acid. deoxyribonucleic acid and protein content during ontogenesis in winter flounder, Pseudopleuronectes americanus, and effect of starvation. Fishery Bulletin 77, 703-708.

Buckley, L. J. (1984). RNA-DNA ratio: an index of larval fish growth in the sea. Marine Biology 80, 291-298.

Bulow. F. J. (1970). RNA-DNA ratios as indicators of recent growth rates of a fish. Journal of the Fisheries Research Board of Canada 27, 2343-2349.

Cesarone, C. F., Bolognesi, C. \& Santi, L. (1979). Improved microfluorometric DNA determination in biological material using 33258 Hoechst. Analytical Biochemistry 100, 188197.

Clemmesen. C. M. (1988). A RNA and DNA fluorescence technique to evaluate the nutritional condition of individual marine fish larvae. Meeresforschung 32, 134-143.

Clemmesen, C. M. (1989). RNA DNA ratios of laboratory-reared and wild herring larvae determined with a highly sensitive fluorescence method. Journal of Fish Biology 35 (Supplement A), 331333.

Clemmesen, C. M. (1990). Improvements in the fluorimetric determination of the RNAand DNA-content in individual marine fish larvae. International Council for the Exploration of the Sea C. M. $1990 /$ L:98.

Dortch. Q.. Roberts, T. L., Clayton, J. R. \& Ahmed, S. I. (1983). RNA/DNA ratios and DNA concentrations as indicators of growth rate and biomass in plank tonic marine organisms. Marine Ecology Progress Series 13,61 71.

Eckmann. R. (1985). Histopathological alterations in the intestine of whitefish (Coregonus sp.) larvae reared on zooplankton From Lake Constance. Diseases of Aquatic Organisms 1, 1117.

Eckmann, R. (1987). A comparative study on the temperature dependence of embryogenesis in three coregonids (Coregonus spp.) from Lake Constance. Schweizerische Zeitschrift für Hydrologie 49, 353-362.

Eckmann, R., Rösch, R.. Ortlepp. J. \& Kleifeld, G. (1986). Survival and growth of coregonid larvae from Lake Constance fed on zooplankton of different origin. Archiv für Hydrobiologie Ergebnisse der Limnologie 22, 203-214.

Haines. T. A. (1973). An evaluation of R NA-DNA ratio as a measure of long-term growth in fish populations. Joumal of the Fisheries Research Board of Canada 30, 195199.

Hunter. J. R. (1984). Interferences regarding predation on the early life stagcs of cod and other fishes. In The Propagation of Coll. Gadus morhua, Part I (Dahl. E.. Danielssen, D. S., Moksness, E. \& Solemdal, P.. eds). pp. 533-562. Flödevigen: Institute of Marine Research.

Klink. A. \& Eckmann. R. (1991). Limits for the detection of daily otolith increments in whitefish (Coregonus lavarerus L.) larvae. Hydrohiologia, in press.

Le Pecq, J.-B. \& Paoletti. C. (1966). A new fluorometric method for RNA and DNA determination. Analytical Biochemistry 17, 100-107.

Martin, F. D.. Wright, D. A.. Means. J. C. \& Setzler-Hamilton, E. F. (1985). Importance of food supply to nutritional state of larval striped bass in the Potomac River estuary. Transactions of the American Fisheries Society 114, 137-145.

May, R. C. (1974). Larval mortality in marine fishes and the critical period concept. In The Early Life History of Fish (Blaxter, J. H. S., ed.). pp. 3 19. Berlin: Springer Verlag.

O'Connell, C. P. (1976). Histological criteria for diagnosing the starving conditions in early post yolk-sac larvae of the northern anchovy Engraulis mordax Girard. Journal of Experimental Marine Biology and Ecology 25, 285-312.

Oozeki, Y.. Ishii. T. \& Hirano. R. (1989). Histological study of the effects of starvation on reared and wild-caught larval stoneflounder. Kareius bicoloratus. Marine Biology 100, 269-275.

Pedersen. B. H., Nilssen, E. M. \& Hjelmeland. K. (1987). Variations in the content of trypsin and trypsinogen in larval herring (Clupea harengus) digesting copepod nauplii. Marine Biology 94, 171-181. 
Purcell. J. E.. Siferd, T. D. \& Marliave, J. B. (1987). Vulnerability of larval herring (Clupea harengus pallasi) to capture by the jellyfish Aequorea v'ctoria. Marine Biology 94, $157-162$.

Robinson. S. M. C \& Ware. D. M. (1988). Ontogenetic development of growth rates in iarvai pacific herrng. Clupeu harengus pallasi, measured with RNA-DNA ratios in the strait of Georga. British Columbia. Canadian Journal of Fisheries and Aquatic siences 45,14221429 .

Theilacker. (j. H. (1986). Starvation induced mortality of young sea-caught jack mackerel. Trachurus smmetricus. determined with histological and morphological methods. Fisher Bulletin 84, $1--17$.

! eherschär. B F R. (1988). Determınation of the nutritional condition of individual marme tish larvae by analyzing their proteolytic enzyme activities with a highly sensitive fluorescence technique. Meeresforschung 32, 144154. 